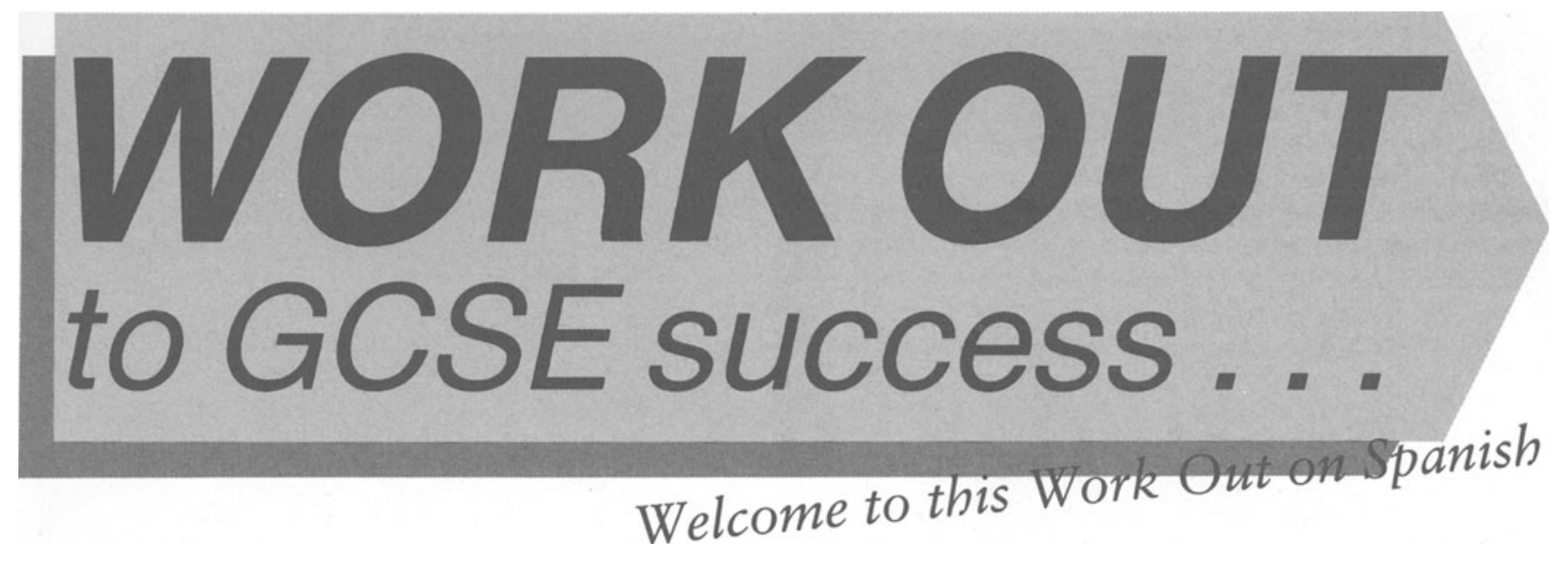

\section{Dear student}

This popular book is for students with some knowledge of spoken and written Spanish who wish to become more proficient in the language and better informed about Spain and the Spanish people.

The book and its accompanying cassette are for those working with or without a teacher to the standard of a good grade in the GCSE Higher or Extended Level. Students with more modest objectives will also be able to devise an appropriate learning strategy, for the material is carefully graded to suit a wide range of ability.

Work Out Spanish has two main objectives:

1 To provide a sound and coherent programme in which the study of authentic materials gives insight into different aspects of Spanish life and serves as a basis for practising the language in realistic contexts.

2 To give specific help to GCSE students because the development of good standards in all the language skills will bring success in examinations for those who seek and work for it.
The series has distinctive features which should help students to study at their own level.

- All the teaching, including the grammatical explanations and exercises, is based on carefully devised texts and recorded dialogues which show the correct use of the contemporary language.

- Elements of grammar and syntax in texts and dialogues are explained and practised by means of graded exercises, for which a key is provided.

- Every care is taken to use the language in sensible situations, avoiding as far as possible pointless or ill-judged questions and exercises.

- A substantial grammar summary clearly explains the basic structures of Spanish and quotes practical examples from the texts or dialogues, so theory is always associated with the practical use of language in context.

Do read the author's introduction closely for details of the book and cassette, as well as valuable suggestions for gaining the full benefit from this established and helpful course.

Yeovil, Somerset Betty Parr Language Series Editor 

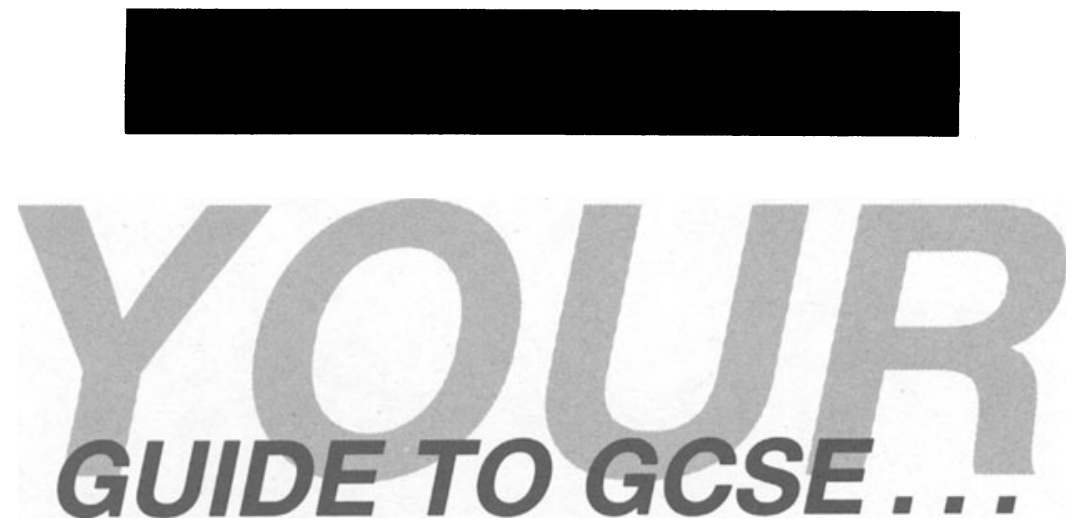

\section{Check your board}

There is variation between exam boards, in the syllabuses and the forms of the exam. For that reason you must be certain which board's exam you will be taking. Of course, your teacher will tell you, and for any details you should write to the board. They can send the full syllabus for your exam including word lists.

\section{Be authentic!}

The National Criteria, which are a sort of checklist, tell us who the exam is for, and what a Spanish course should do. They ask for the kind of Spanish which you need to understand and use when dealing with Spanish people who are in Britain, or whom you meet travelling in Spain or another Spanish-speaking country.

So the Spanish materials you study must be 'authentic'. When you do a listening or a reading task, the setting and the content are taken from real life, and from the situations where you hear spoken Spanish and read the language in signs, adverts, articles and public notices.

\section{Skills and grades}

For the exam, language is divided into the four main skills, Listening, Speaking, Reading and Writing. Each of these skills is tested separately. There are also two levels of examination - called Basic, and Higher or Extended. You can choose which skills and which levels you want to be examined in, which is another advantage of the new system. But you must do the common core. This consists of:

- Basic Listening

- Basic Reading

- Basic Speaking.

In the whole scale of GCSE grades which go from A to $\mathrm{G}$, the common core can gain a maximum of Grade $\mathrm{E}$. As you add on extra elements, your possible maximum grade increases by one each time, as you can see from this table:

\begin{tabular}{|c|c|c|c|c|c|c|c|c|c|c|c|}
\hline GRADE & $\begin{array}{c}\text { BASIC } \\
\text { LISTENING }\end{array}$ & & $\begin{array}{l}\text { SIC } \\
\text { DIN }\end{array}$ & & & $\begin{array}{c}\text { BASIC } \\
\text { SPEAKING }\end{array}$ & $\begin{array}{c}\text { BASIC } \\
\text { WRITING }\end{array}$ & $\begin{array}{c}\text { HIGHER } \\
\text { LISTENING }\end{array}$ & $\begin{array}{c}\text { HIGHER } \\
\text { READING }\end{array}$ & $\begin{array}{l}\text { HIGHER } \\
\text { SPEAKING }\end{array}$ & $\begin{array}{c}\text { HIGHER } \\
\text { WRITING }\end{array}$ \\
\hline A & $\mathrm{TH}$ & E & C & 0 & $\mathrm{R}$ & E & COMPULSORY & \multicolumn{3}{|c|}{ CHOICE OF 2 OF THESE 3 ELEMENTS } & COMPULSORY \\
\hline B & $\mathrm{T} \mathrm{H}$ & E & $\mathrm{C}$ & 0 & $\mathrm{R}$ & E & COMPULSORY & \multicolumn{3}{|c|}{ CHOICE OF 1 OF THESE 3 ELEMENTS } & COMPULSORY \\
\hline $\mathrm{C}$ & $\mathrm{T} \mathrm{H}$ & E & $\mathrm{C}$ & 0 & $\mathrm{R}$ & E & COMPULSORY & \multicolumn{4}{|c|}{ CHOICE OF 1 OF 4 HIGHER ELEMENTS } \\
\hline $\mathrm{D}$ & $\mathrm{TH}$ & E & $\mathrm{C}$ & 0 & $\mathrm{R}$ & E & \multicolumn{5}{|c|}{ CHOICE OF 1 OF 5 NON-CORE ELEMENTS } \\
\hline $\mathrm{E}$ & $\mathrm{TH}$ & E & C & 0 & $\mathrm{R}$ & E & & & & & \\
\hline $\mathrm{F}$ & $\mathrm{TH}$ & E & $\mathrm{C}$ & 0 & $\mathrm{R}$ & E & & & & & \\
\hline G & $\mathrm{TH}$ & $\mathrm{E}$ & C & 0 & $\mathrm{R}$ & $\mathrm{E}$ & & & & & \\
\hline
\end{tabular}




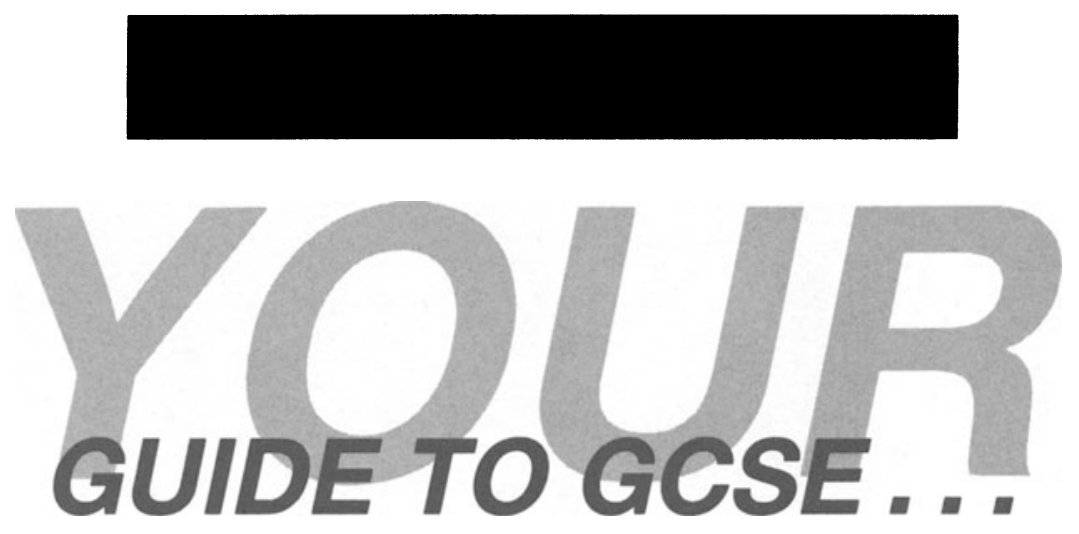

Most people who are aiming at Grades A or B do all eight elements (Basic Listening, Speaking, Reading and Writing, and the same four skills at Higher Level). Most people aiming at Grade $\mathrm{C}$ do all four Basic tests and at least two Higher tests (usually, but not always, Listening and Reading). One board (MEG) divides the Higher Level papers into Part 1 and Part 2.

\section{The form of the exam}

The form of the exam varies from board to board. Some boards set all the Basic Level papers in one sitting and all the Higher Level papers in another sitting on a different day. Others group papers by skills, and have Basic Level Listening followed by Higher Level Listening, etc. Whichever board you do, you will only have one oral exam, either at Basic, or at Basic + Higher Level. The oral will be conducted by your own teacher. It will be held earlier than the other parts of the exam.

\section{Points and grades}

The last thing to explain is the grading system. For each element of the exam, the marks you score are converted into a number of points. The total number of points you get decides your grade. Here is an example of how this works:

Total number of points available for each element

\begin{tabular}{l|c|c|c|c} 
& Listening & Reading & Speaking & Writing \\
\hline Basic & 4 & 4 & 4 & 4 \\
\hline Higher & 3 & 3 & 3 & 3 \\
\hline
\end{tabular}

Total $=28$ points
Points required for each grade:

\begin{tabular}{c|c|c|c|c|c|c|c} 
Grade & A & B & C & D & E & F & G \\
\hline Points & $24-28$ & $21-23$ & $18-20$ & $14-17$ & $10-13$ & $5-9$ & $1-4$ \\
\hline
\end{tabular}

If you are aiming at Grade $C$ you need at least 18 points, so you must take all four Basic elements + at least one Higher element. This would give you a maximum possible score of 19 points if you got all the points in each part of the exam. To be sure of your grade it would be better to take at least two if not three Higher elements.

To get all four points in a Basic Level exam, you do not have to get full marks, but generally you have to get about $80 \%$. To get at least one point at Higher Level you normally have to get about $35-40 \%$.

The system seems very complicated, doesn't it? Now for the good news! Because of the points system, it is easier to get a Grade $A$ in Spanish (and other languages) than in any other subject. About $20 \%$ got Grade A in the first two years of the exam. So, aim high, take all the elements you have a reasonable chance of scoring a point in. (It doesn't cost more if you take three elements or all eight.) And Good Luck! or rather, „Buena suerte!

Well done! You chose Work Out for its complete coverage 


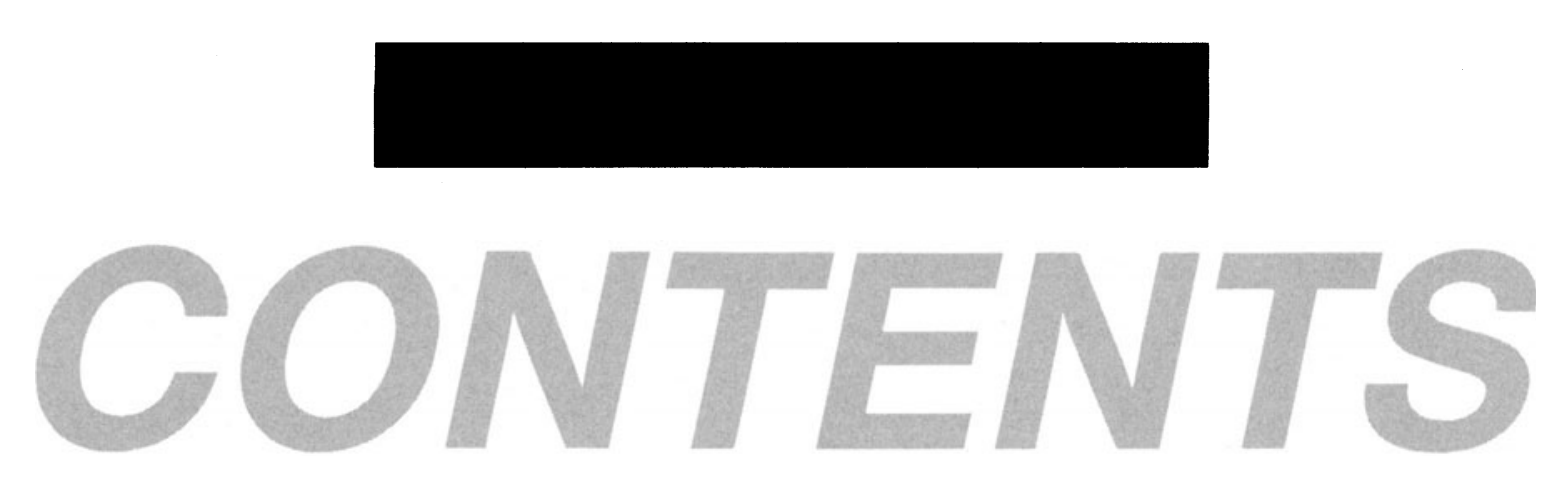

Introduction 8

Pronunciation Guide 9

La Vida Familiar 46

La Vida de la Ciudad 11

Una Región Española - Galicia 51

La Vida del Campo 15

El Turismo en España 55

En el Instituto 20

El Teatro Español (Federico García Lorca) 61

La Prensa Española 65

La Gastronomía 25

Las Fiestas Religiosas 70

De Compras 29

El Patrimonio Nacional 76

Los Jóvenes de Hoy 33

Los Jóvenes Adultos en España -

El Cine Español 37

sus Actitudes y Opiniones 82

El Ocio 41

La Nueva Democracia 90 
La Corrida de Toros 97

Recursos e Industria 104

España, País de Contrastes 112

\section{Grammar Summary 121 \\ Index to Grammar \\ Summary 142}

Key to Exercises 143

Bibliography 166 


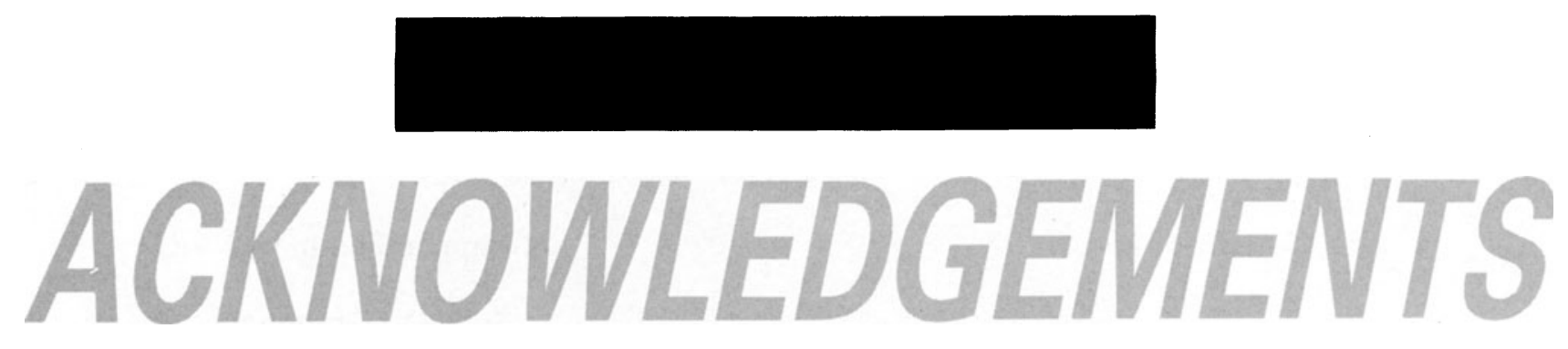

The author and publishers wish to thank the following for permission to use copyright material: the London East Anglian Group; Midland Examining Group; Northern Examining Association, comprising Associated Lancashire Schools Examining Board, Joint Matriculation Board, North Regional Examinations Board, North West Regional Examinations Board and Yorkshire \& Humberside Regional Examinations Board; Northern Ireland Schools Examinations and Assessment Council; Southern Examining Group; University of Oxford Delegacy of Local Examinations and the Welsh Joint Education Committee for questions from past examination papers.

Every effort has been made to trace all the copyright holders but if any have been inadvertently overlooked the publishers will be pleased to make the necessary arrangement at the first opportunity.

The London East Anglian Group accepts no responsibility whatsoever for the accuracy or method in the answers given in this book to actual questions set by the Group.

The Southern Examining Group and the University of Oxford Delegacy of Local Examinations wish to point out that worked examples included in the text are entirely the responsibility of the author and have neither been provided nor approved by the Group.

The author would like to thank Angel Palomo for his help in checking the proofs, his son Philip for his help in typing the manuscript, and both his son Chris and Mrs Kim Wooldridge for their help with some of the artwork. The publishers would like to thank the Spanish National Tourist Office and Robert P. Clarke for the use of photographs, and Ted Neather for his GCSE guide. 


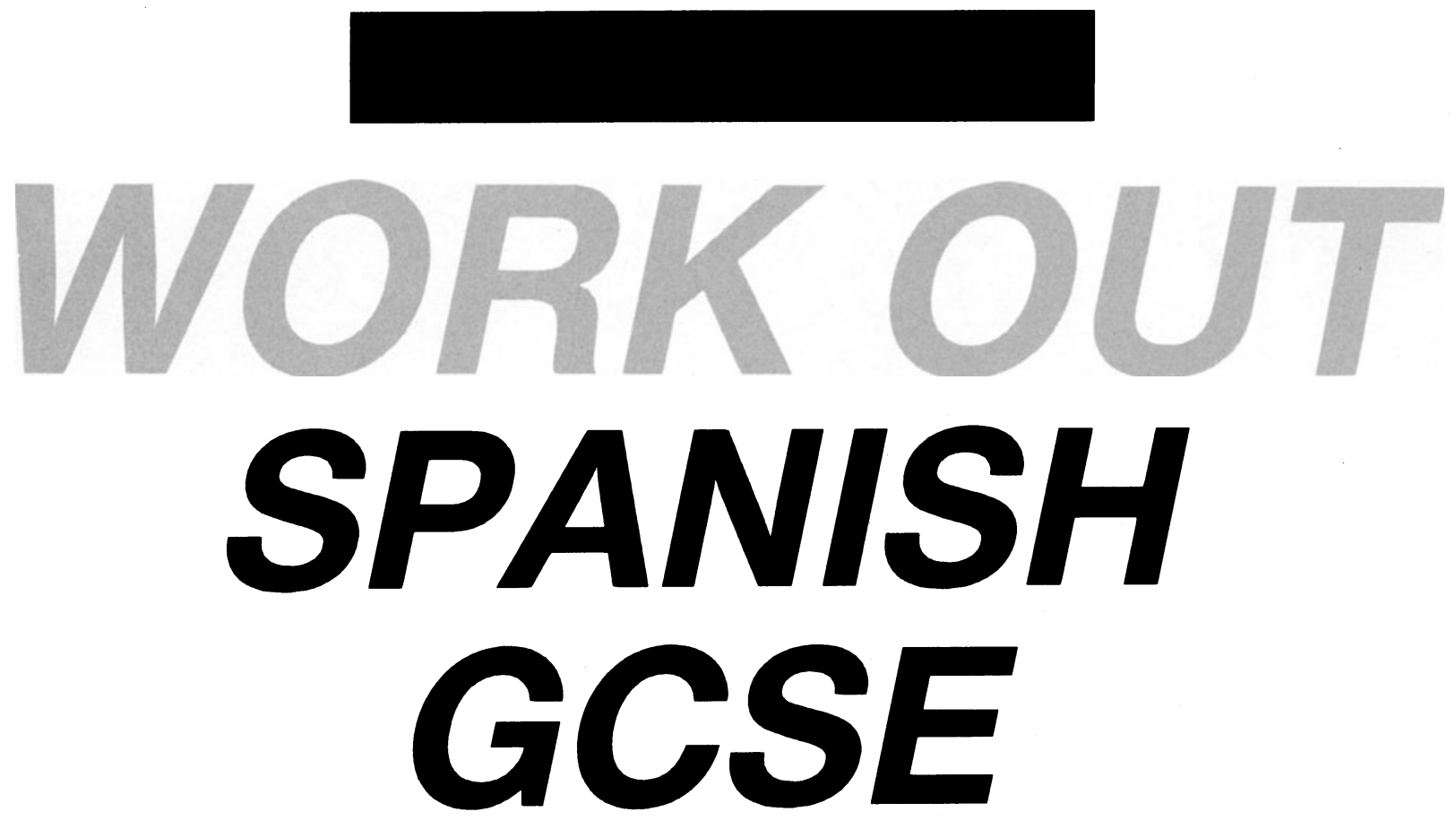

Robert Taylor

Editorial Consultant Betty Parr 